\title{
Locality, belonging and the social meanings of Afrikaans rhotic variation in the South Cape: from patterns of frequency towards moments of meaning
}

\author{
Yolandi Ribbens-Klein \\ University of Cape Town
}

Correspondence to: +27216502039; yolklein@gmail.com

\begin{abstract}
Since Labov's ground-breaking work in 1966, there have been significant changes to the ways that social meanings of linguistic variation are perceived and studied by variationist scholars. These changes are driven by an impetus to move from a focus on the description of the social correlates of linguistic variation, towards exploring the processes involved in how linguistic variables attain indexical social meanings. This paper contributes to explorations of the social meanings of linguistic variation, and also provides current research to the dearth of studies on Afrikaans varieties. The data are from my $\mathrm{PhD}$ project, which investigates how people in a town in the South Cape region (Western Cape Province in South Africa) use the Afrikaans (r) to index locality, belonging, and other forms of social meanings, particularly in the context of social and geographic mobility (Ribbens-Klein, 2016). Conventional variationist sociolinguistics has focused mainly on macro-social groups, but in this paper, I choose to focus on one individual and the multiple indexical meanings of rhotic variation. I discuss three different sets of results: metalinguistic comments, the frequency use of rhotic variants, and the use of variants in interaction. This study aims to demonstrate that the frequency use of a variant is but one aspect involved in the social meanings of linguistic forms in interaction.
\end{abstract}

Key words: Afrikaans linguistic variation, extreme locality, indexicality, moments of meaning, social meanings

* Acknowledgments: I wish to thank Prof Rajend Mesthrie for continued support, especially through his NRF (National Research Foundation) SARChI research chair (grant no. 64805, Migration, Language and Social Change). I also thank all the participants in the study who gave generously of their time. Finally, thanks to the reviewers for constructive feedback. 


\section{INTRODUCTION}

Since Labov's ground-breaking work $\checkmark$ in 1966, there have been significant changes to the ways that social meanings of linguistic variation are perceived and studied by variationist scholars. These changes are driven by an impetus to move from a focus on the description of the social correlates of linguistic variation, towards exploring the processes involved in how linguistic variables attain indexical social meanings. This paper contributes to explorations of the social meanings of linguistic variation, and also provides current research to the dearth of studies on Afrikaans varieties. The data are from my $\mathrm{PhD}$ project, which investigates how people in a town in the South Cape region (Western Cape Province in South Africa) use the Afrikaans (r) to index locality, belonging, and other forms of social meanings, particularly in the context of social and geographic mobility (RibbensKlein, 2016). ${ }^{1}$ Conventional variationist sociolinguistics has focused mainly on macro-social groups, but in this paper, I choose to focus on one individual and the multiple indexical meanings of rhotic variation. As argued by Johnstone and Kiesling (2008; also see Johnstone, 2000), speakers' social uses of linguistic forms involve language ideologies that also reflect their own personal histories and experiences. I discuss three different sets of results: metalinguistic comments, the frequency use of rhotic variants, and the use of variants in interaction. The metalinguistic comments made by Lionel (aged 18; the individual I focus on) show that the social meanings of (r) involve experiences of being local in one's own neighbourhood, drawing on the extremely local (Williams and Stroud, 2010). Quantitative analyses indicate how Lionel's (r) variants are embedded in broader patterns of variation according to macro-social groupings such as gender and age. He has the two main (r) variants alveolar-r and uvular- $r$ - in his repertoire, and I argue that he can strategically use variation to index meaningful moments during interactions. This study aims to demonstrate that the frequency use of a variant is but one aspect involved in the social meanings of linguistic forms in interaction.

\section{BACKGROUND: HOUTINIQUADORP}

The participants in the larger study are residents from a peri-urban, Afrikaansdominant town. In the early nineteenthcentury, the area was inhabited by Houteniquas, who were a regional Khoekhoe group. I refer to the town as Houtiniquadorp to protect the participants' anonymity. The pseudonym reflects the complex entanglement of the place's pre-colonial heritage with the postcolonial reality in which Afrikaans is the most spoken language in the area. The Afrikaans word dorp ('town') embodies the colonial history of which Afrikaans itself is a product.

ThedevelopmentofHoutiniquadorp was influenced by the establishment of a mission station by the London Missionary Society in the early nineteenth-century. Present-day Houtiniquadorp is home to 25,275 residents, where $91.1 \%$ of residents reported to use Afrikaans as a home language and $92.3 \%$ selfidentified as being from the Coloured

1 Bracket conventions: /r/ indicates phoneme; (r) indicates linguistic variable; [r] indicates linguistic variant/s. 
population group (StatsSA, 2012). ${ }^{2}$ Houtiniquadorp was demarcated as a Coloured area during apartheid with the Group Areas Act (Act 41 of 1950), which saw residential segregation according to racial population groups. There is no straight-forward answer to what "Coloured" identity means today, because this apartheid construct conflates and obscures the social and ethnic diversity of the people to whom it was applied. In South Africa, the term Coloured does not refer inclusively to all "people of colour". Instead, this racial label was 'created during the nineteenthand early twentieth-centuries as an administratively convenient catch-all term for people of very varied origins and not in all cases of mixed descent' (Branford, 1996: 41). The Coloured category includes people with Khoekhoe or slave roots, as well as those with mixed European/Khoekhoe/slave ancestry. ${ }^{3}$ However, racial classification is not coterminous with identity-formation, and for some people, Colouredness involved/involves specific social identity formations. The participants' opinions about Colouredness can be summarised in three main stances: Colouredness as an intermediate status in South Africa's essentialist racial hierarchies (between White and Black); Colouredness as a valid identity that involves hybridity and fluidity; and anti-Coloured, proindigenous Khoesan revivalism as a form of identity politics driven by aims for self-determination (also see Adhikari, 2006; Erasmus, 2001).
In 1995, Houtiniquadorp became part of George, a town situated between the Indian Ocean and the Outeniqua Mountains in the Western Cape (see figure 1; the star roughly indicates the location of Houtiniquadorp). At present, George is the largest town in the South Cape Garden Route and comprises several residential areas, but many residents regard Houtiniquadorp to be a town separate from George, which relates to the history of the place.

Houtiniquadorp has continuously accommodated new residents, so-called inkommers (lit. 'incomers'; translated as 'newcomers'). Inkommer is a broad label that includes recent arrivals, people not born in Houtiniquadorp, and in some cases, people whose parents and grandparents were not born in the town. Thus, the meaning of the label depends on the person using it and the context in which it is used. The term boorlinge (lit. 'bornlings', cf. 'earthlings'; translated as 'locals') is used in relation to inkommers, and refers to a select group of people from several different families, many of whom have strong generation ties to the town. The local distinctions between boorlinge and inkommers is not a recent phenomenon, nor is it restricted to Houtiniquadorp. Waldman (2007: 133) states that these categories are well established in the literature on some of South Africa's Coloured communities. She argues that these categories are ambiguous and flexible, where the distinctions are negotiated and manipulated according to various

2 The South African Population Registration Act (Act 30 of 1950) used the labels White, Black (African), Coloured, and Indian for South African population groups. My use of these terms follows their application in official statistics to refer to groups 'with common characteristics (in terms of descent and history), particularly in relation to how they were (or would have been) classified before the 1994 elections' (Statistics South Africa, cited in Christopher, 2005: 2307).

3 About 60,000 slaves were brought into the Cape Colony between 1652 and the abolition of the overseas slave trade in 1807. These slaves mainly originated from Indonesia, India, Madagascar and the east coast of Africa (Ross, 2004: 6). 


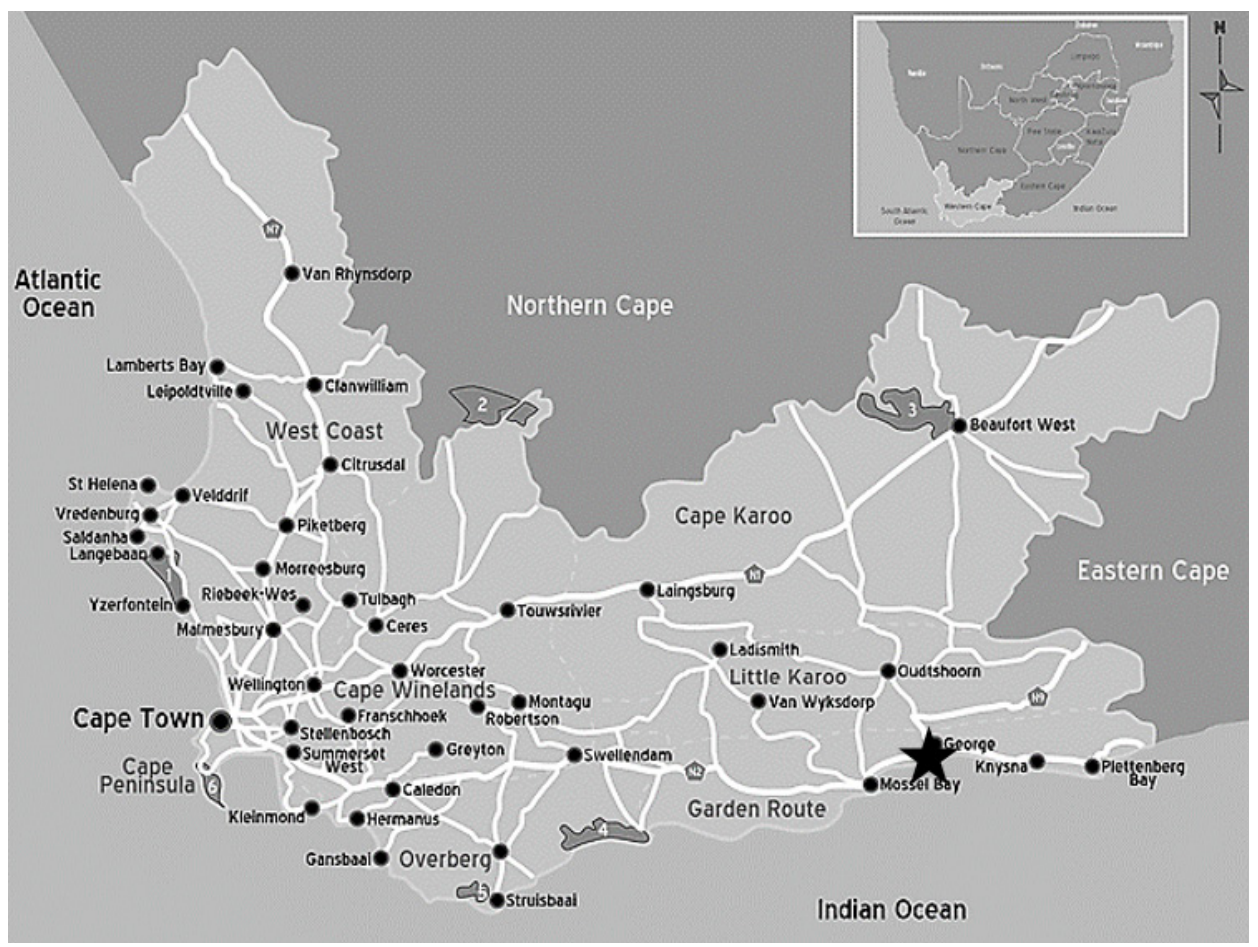

Figure 1. Map of the Western Cape Province, indicating the research site ${ }^{4}$

social contexts. The boorling/inkommer distinction is also reflective of more recent changes in Houtiniquadorp: the boorlinge's perceptions of social changes through increased in-migration led to a (re)formulation of belonging: legitimate residents (boorlinge) versus unwelcome intruders (inkommers).

Social stratification in the neighbourhoods further complicates the meaning of boorling and inkommer. The boorling/ inkommer distinctions were visible in the three main neighbourhoods where I conducted fieldwork, and contributed to local socioeconomic power struggles. Social and geographic mobilities are involved in the perceptions Houtiniquadorpers have of the different neighbourhoods and types of residents living there. Old Dorp ('Old Town') consists of the oldest Houtiniquadorp neighbourhoods where mostly boorlinge live on family owned land. Scheme is a local name for the low-cost housing neighbourhoods associated with impoverished inkommers and boorlinge. Bergview is the more affluent neighbourhood at the fringe of the town where more socially mobile boorlinge and inkommers reside. Figure 2 is a Google map of Houtiniquadorp, depicting these three areas. The arrow in figure 2 indicates a

4 Source: Mapsof.net (2014). Online: http://mapsof.net/map/south-africa-western-cape-map\#. UGBvEo3ZDjI. 


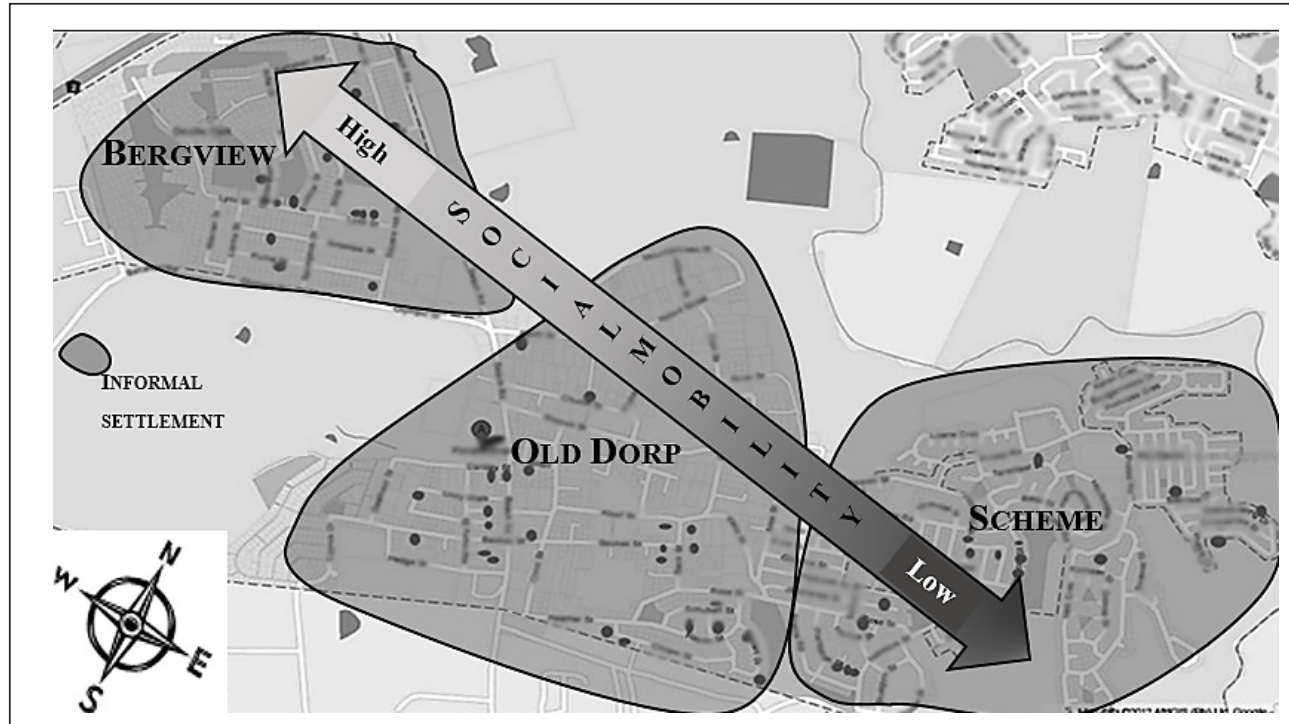

Figure 2. Google map of Houtiniquadorp showing three research areas (dots indicate residences of participants)

trajectory of social mobility associated with the neighbourhoods, ranging from high social mobility in Bergview, to low social mobility in Scheme.

\section{THEORETICAL FRAMEWORK}

\section{Linguistic variation and social meanings}

Eckert (2012) provides a useful account of changes and developments with regard to the conceptualisation of social meaning and linguistic variation in sociolinguistics by using the analogy of three waves. Each wave is defined by methodological and analytical developments. By showing that linguistic variation is governed by ordered heterogeneity and exhibits distribution patterns according to social variables, first- and second-wave studies paved the way for third-wave sociolinguistics. The main perspective of third-wave studies is that linguistic variation is not the reflection of social identities and categories (local or otherwise); rather, variation forms part of broader social practices, and 'speakers place themselves in the social landscape through stylistic practice' (Eckert, 2012: 92-93). According to Eckert, thirdwave studies can enable sociolinguistic research to proceed from empirical observations about the meaningfulness of a linguistic variable towards fostering the understanding of how it came to be socially meaningful in the first place. For example, in Eckert's own (1989; 2000) ethnographic and sociolinguistic study of language variation in a Detroit high school she found that the students' use of phonetic variables did not merely reflect their gender or socioeconomic status. She identified (emic) localised social groupings in the school (labelled by the students as 'Jocks', 'Burnouts', and 'In-betweens') and found that the meaning(s) of the linguistic variables were constructed locally around salient 
ideological issues (such as conforming or rebelling within the school context). Furthermore, the students used linguistic variation as a resource to index social styles, rather than macro-social identities, just as explicitly as they do with their different hairstyles, nail polish and clothing. Third-wave studies focus on how speakers as agents reflexively employ variables to produce and reproduce contextualised social structures. Reflexivity (as used here) refers to the states of 'agentive consciousness' of people acting in social situations, 'so that language use is appropriate to particular contextual conditions and effective in bringing about contextual conditions'; i.e. reflexivity is part of speakers' metapragmatic awareness (Silverstein, 2006: 462-463).

\section{Silverstein's indexical orders}

The notion of indexical order refers to semiotic processes whereby linguistic forms become associated with social meanings. It was developed by the linguistic anthropologist Silverstein and is based on the philosopher Peirce's (1931-1936) triadic approach to the sign, namely iconic, indexical, and symbolic (Peirce, 1955: 102-115). Peirce's concept of the indexical sign-relation is specifically important for studying linguistic variation as 'a robust social semiotic system’ (Eckert, 2012: 87). Apart from being a mechanism for linguistic change, variation of linguistic forms has social meanings that point to aspects of socially or culturally meaningful contexts (Ahearn, 2012: 28).

Silverstein (2003) argues that we can distinguish various orders of indexicality, where the index itself has firstness $(n-t h$ order $), \quad$ secondness $(n+1$-th-order $)$, and thirdness $((n+1)+1$-th-order $)$. In the indexical orders, language users associate different degrees of social meaning between the linguistic form (as a sign) and micro-social context-of-use. The first-order $(n-t h)$ is on the pragmatic level, the second-order $(n+1-t h)$ is on the metapragmatic level, and the third-order $((n+1)+1-t h)$ involves metapragmatics on the level of ideological and conventionalised discourses (Lacoste et al., 2014: 4-5). Metapragmatic awareness is a speaker's ability to recognise the usual or expected context for the use of certain linguistic expressions; this awareness is tied to certain properties of the linguistic signs (e.g. as markers of politeness) that presuppose or entail contexts-of-use (Silverstein, 1981, 1985, 1993). Presupposition, in Silverstein's definition, is 'appropriateness-tocontext', where the meaning of the index is 'already established between interacting sign-users', albeit implicitly (Silverstein, 2003: 195). With entailment, a sign's 'effectiveness-in-context' is brought to being (i.e. created) by the usage of the indexical sign. Presupposition therefore works on the association of the indexical to context-of-use, and with entailment, the sign-user creates a new context-ofuse (Silverstein, ibid.; also see Eckert, 2008 discussed below). According to this model, indexical meaning-making does not stop at a third-order level. The potential is there for 'unlimited further orders of indexicality', which motivates the continuous process of changing linguistic patterns and ideologies (Woolard, 2008: 437-438).

Speech style, as an intra-speaker variable, is a theoretical construct that allows Labov ([1966] 2006:64) to describe language use as being located on a continuum of casual to formal speech. Silverstein (2003: 218) refers to Labov's speech styles as different instances of 'contextual style'; i.e. speakers respond to the register-demands of the different 
interactional contexts, and these register-demands are culturally specific. Thus, the interview can also be seen as a specific genre and a particular type of situated speech. It is not necessarily constructed as being formal or informal (Duranti, 2009: 7). Therefore, one works with the assumption that speakers share similar metapragmatic awareness about appropriate or effective ways of speaking in interactional contexts (Silverstein, 2003: 219). Speakers' metapragmatic awareness relates to individual and group notions of what the purpose of the interaction is. In this paper, I focus on an individual in interaction, which allows me to move beyond casual, conversational or formal, careful styles to investigate how participants use variation during micro-interactional moves - or moments of meaning - across and within conversational topics. Thus, I consider not only factors external to the speaker (e.g. speech situation, audience, and topic), but also factors involved in speakers' projection of a particular type of persona (Schilling-Estes, 2002; Coupland, 2007; Mendoza-Denton, 2007).

\section{Eckert's formulation of the indexical field}

Eckert (2008) formulates a heuristic called the indexical field to show how a linguistic form has multiple and fluid social meanings, which are ideologically linked and activated 'in the situated use of the variable' (2008: 454). The indexical field shows how speakers use linguistic variation to situate themselves within a field of potential social meanings: 'an indexical field is a constellation of meanings that are ideologically linked' (2008: 463). Eckert draws on Silverstein's (2003) notion of indexical orders, and she argues that the potential indexicality of linguistic forms are activated 'in the situated use of the variable' (2008: 454). Since the indexical field involves ideologies about contexts and types of speakers (i.e. metapragmatics), the field is not fixed but fluid, and thus 'has the potential to change [...] by building on ideological connections'; variation, as an indexical system, 'embeds ideology in language and that is in turn part and parcel of the construction of ideology' (Eckert, 2008: 454). Eckert's formulation of the indexical field should not be viewed as a static constellation of social meaning and interactional stances; the indexical field encapsulates the multiplicity and indeterminacy of social meaning in social contexts (Johnstone and Kiesling, 2008). Eckert's (2008) indexical fields show that speaker agency is involved when speakers make interactional moves in the indexical field of a variant's multiple and shifting social meanings. In this study, I use qualitative and quantitative data to produce indexical fields for Afrikaans $/ \mathrm{r} /$.

\section{QUANTITATIVE AND QUALITATIVE METHODOLOGY}

\section{The linguistic variable (r)}

The linguistic form I focus on is Afrikaans /r/. Rhotics, as a class of sounds, have highly variable phonetic realisations and can 'both be an opportunity and a challenge to variationists' (Scobbie, 2006: 337-338). Rhotics are informally referred to as 'r-sounds' (Ladefoged and Maddieson, 1996: 215). Afrikaans $/ \mathrm{r} /$ has various variants and allophonic realisations. Afrikaans phonetics texts describe alveolar trill [r] as standard, and uvular-r (trill $[\mathrm{R}]$ or fricative $[\mathrm{\textrm { }}]$; bry-r; 'burr') as a non-standard, regional feature 
(De Villiers and Ponelis, 1987; Odendal, 1989). I investigated variation between alveolar-r and uvular-r. I consider the frequency of zero-r as a phonological and stylistic feature. The $(r)$ variants were analysed impressionistically, because the articulatory differences between alveolar-r, uvular-r, and zero-r are distinct.

\section{Data collection and analyses}

My data collection methods were semistructured sociolinguistic interviews and ethnographic fieldwork conducted over two years. Staying in the town for stretches of time allowed me to get a sense of the place and its people. The interviews were audio-recorded in the participants' homes, and a few were done in workplaces. Some participants with difficult home situations were interviewed at their local church. Using the qualitative data analysis programme MAXQDA 11 (VERBI GmbH., 19952014), I coded each transcribed interview according to key words, topics and themes, which enabled me to observe shared and contesting discourses about place and belonging, as well as metalinguistic comments. The excerpts used in this paper are all translated from Afrikaans by me.

(r) tokens were extracted from conversations during the interview (casual style), as well as wordlist-style picture descriptions (careful style). Picture descriptions were successful for elicitation of (r) variants in Tops' (2009: 7) study of (r) variation in Flanders, and I compiled my own sets of clipart pictures. To investigate the factors conditioning alveolar-r and uvular-r use, I used mixed effects models in Rbrul (Johnson, 2009) and R (R Core Team, 2014). The independent variables were Gender, Age, Neighbourhood, Residential Status
Score (RSS), and Speech Style. I also used cluster analyses in SPSS (IBM Corp, 2012) as exploratory methods to see whether the 72 participants form clusters according to their (r) use.

\section{RESULTS AND DISCUSSION}

I present three different sets of results, which all investigate the potential indexical orders of Afrikaans (r) in Houtiniquadorp, by focusing on one individual, Lionel. An only child, Lionel lived with his parents in a modest house in the Scheme. His father is from a boorling family, while his mother also has family connections in Houtiniquadorp, but spent a large part of her childhood in Johannesburg. At the time of the interview, Lionel was eighteen years old. He spent his days playing video games and soccer with friends, watching movies and helping out with his father's local rugby team. He was unsure about his future, because he did not complete high school, and he intended to focus on a career in soccer.

\section{Never-mind attitude, locality and extreme locality}

Afrikaans speakers are generally aware of the different r-sounds, especially if they are from an area where the bry-r (i.e. uvular-r) is used. In terms of indexicality, speakers frequently associate uvular-r with very specific regions. The common stereotypical bry area is the Swartland, especially the town Malmesbury, with the Overberg to a lesser extent (see Boonzaier 1982, 1989). In the main study, the metalinguistic comments show that some participants regard uvular-r as local, while others attribute either no social meaning to it, or meanings related to other social aspects (Ribbens-Klein, 
2016). Uvular-r forms part of many Houtiniquadorpers' repertoires (also see below), and the results show that while uvular-r is a regional stereotype or dialect feature, the sound has various other non-place meanings that not only index macro-social categories (such as socioeconomic status, gender and age); the metalinguistic comments show that uvular-r can index multiple and indeterminate meanings in Houtiniquadorp that are tied to subjective experiences of locality and belonging.

I initiated a metalinguistic discussion with Lionel by asking him whether he could hear if people from other areas sounded different from Houtiniquadorpers. He immediately referred to the way people in Oudtshoorn pronounce their $/ \mathrm{r} /$, which he found different than 'their' (i.e. Houtiniquadorpers') /r/, and he explained hat some Houtiniquadorpers bry, and some do not. I wanted to know if there were specific people in Houtiniquadorp who bry, and in his explanation, he associated bry with people in his Scheme neighbourhood: ${ }^{5}$

1.

Lionel: Like in, people who here, here in this area, stay here, some of them burr.

Yolandi: Which area?

Lionel: $\quad$ This is Ocean Park, we just say the Scheme. Yes, so, one will easily recognise people, like we who live here now, will indeed easily recognise people if they are from the Scheme.

Yolandi: Why?

Lionel: $\quad$ Just the, the, like they do things and, /let me see/, dress like that, like they now do, yes.
Yolandi: Is it? How do they dress?

Lionel: $\quad$... They don't worry what other people think, like that. They're so never-mind, [like that] they will dress, yes.

Lionel stated that the specific people who bry were residents of the workingclass neighbourhood where he lives, colloquially called the Scheme(seeSection 2). Lionel associated bry with broader social practices of certain residents from the Scheme, such as a don't worry or never-mind attitude of Scheme residents, who have a carefree approach to what others think about them. Tracksuits were a style of clothing that I saw frequently in the neighbourhood, especially among teens and young adults. The photograph in figure 3 shows this style.

Lionel explained that one could easily recognise someone from Scheme through their behaviour and dress style, where the never-minded attitude is an example of social practice on the stylistic level (similar to what has been described by Eckert, e.g. 2000). Thus, he discursively constructed the indexical association between bry and a never-minded attitude or style. Therefore, bry can indirectly index working class by being associated with youth from the Scheme who, through the current situation of unemployment (see Section 2), walked the streets strutting in never-mind clothing styles and bry-ing.

While our discussion started with Lionel stating that van ons bry ('some of us burr'), he switched from using the pronoun ons ('us') to hulle ('they') when talking about the never-minded attitude. He did not include himself in the group with the never-minded style, but when I continued asking him about uvular-r use

5 Transcription conventions used: / indicates a break; [ ] indicates word(s) added for clarity; and ... indicate word(s) omitted. 


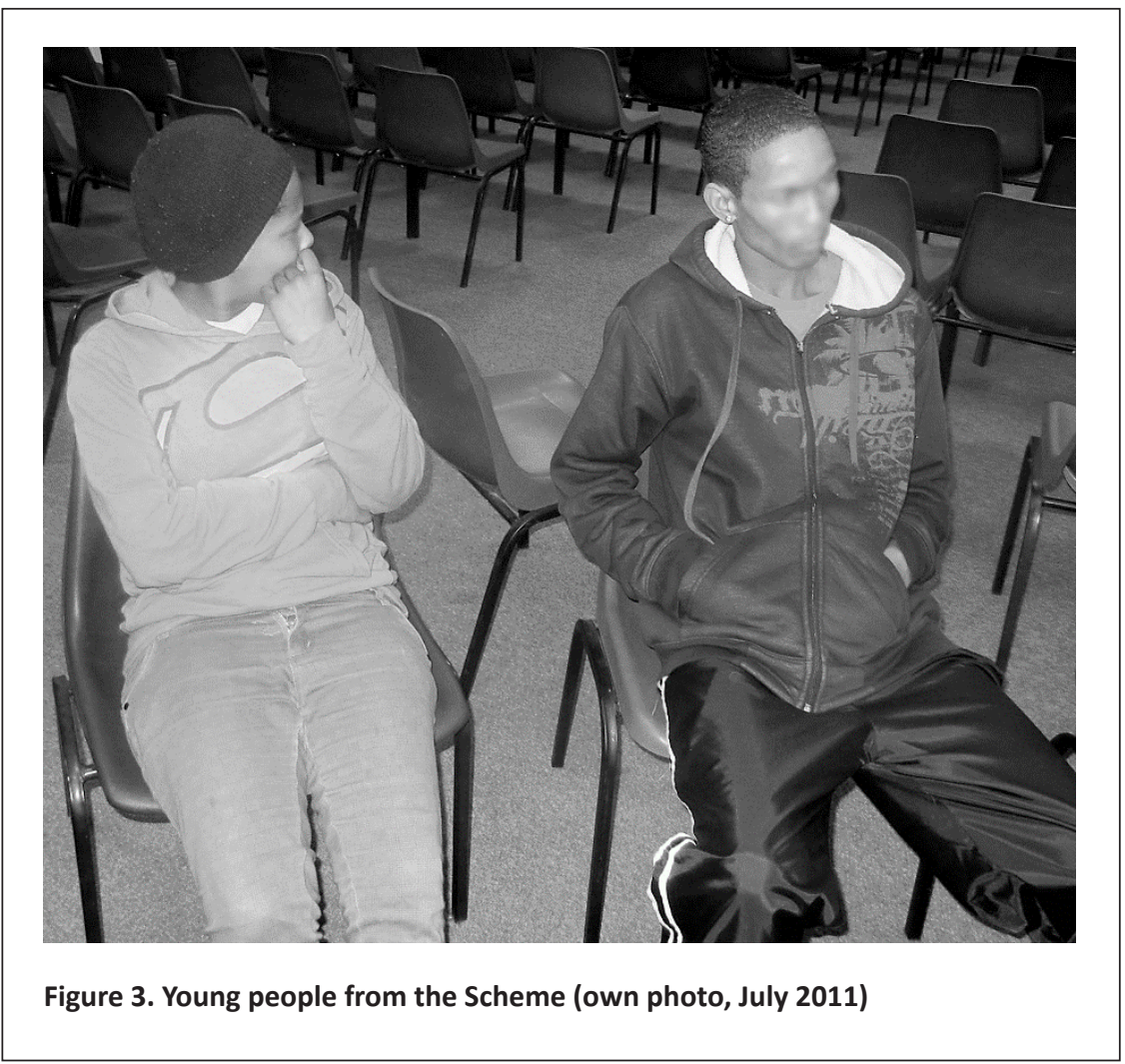

in the Scheme, he made an interactional move that put him back into the 'us' realm:

2. Yolandi: And is it they who burr, or youplural who burr?6

Lionel: Just yes, is like, most of, just its everywhere rather, us Brown ${ }^{7}$ people who burr, like that.

Lionel moved from the local to the supraregional when he included uvular-r as indexical for Coloured (or Bruin, 'Brown') people in general. Here uvular-r moves from indexing locality, towards indexing broader ethnic identity.

Furthermore, Lionel stated that not everyone from the Scheme used the bry it was particularly younger speakers who bry:

3 .

Yolandi: But the people in the Scheme don't really burr?

Lionel: Not really, but some of them, some of the little guys. They are brought up like that.

Yolandi: Okay, not the older ones?

Lionel: $\quad$ No.

Yolandi: Is it then incomer people or?

Lionel: $\quad$ No, they are simply from here.

6 Afrikaans distinguishes between singular and plural second-person pronouns: jy (singular 'you') and julle (plural 'you'). In the translations, I indicate plural second-person pronouns as 'you-plural'.

7 Instead of Kleurling ('Coloured'), Lionel used Bruin ('Brown'), which is an Afrikaans term preferred by some people, because it is regarded as less derogatory than the apartheid word Kleurling. 
According to Lionel's experience of growing up in the Scheme, children were socialised into using uvular-r: his responses show that in the Scheme, younger speakers were using uvular-r while older residents did not. The Scheme neighbourhood has extensive low-cost housing areas, which Houtiniquadorpers associated with an influx of inkommers ('incomers'). In an attempt to see if Lionel associated the bry with new residents in the neighbourhood, I asked whether it was inkommers who bry. His response indicates that while he did not see bry as a specifically Houtiniquadorp or local feature, it also did not index outsiders or strangers.
Looking at the full interaction of approximately two minutes in duration, Lionel twice moved from the general to the specific. Where he first associated uvular-r with the Scheme, he then specified those with a never-minded style; i.e. he moved from locality to 'extreme locality' (Williams and Stroud, 2010). Williams and Stroud (2010) employ the notion of 'extreme locality' to explain how multilingual Capetonian hip-hop artists draw on various local social meanings to amplify their authenticity in their performances. They define extreme locality as 'a space that binds participants together around a common understanding of the local bric and

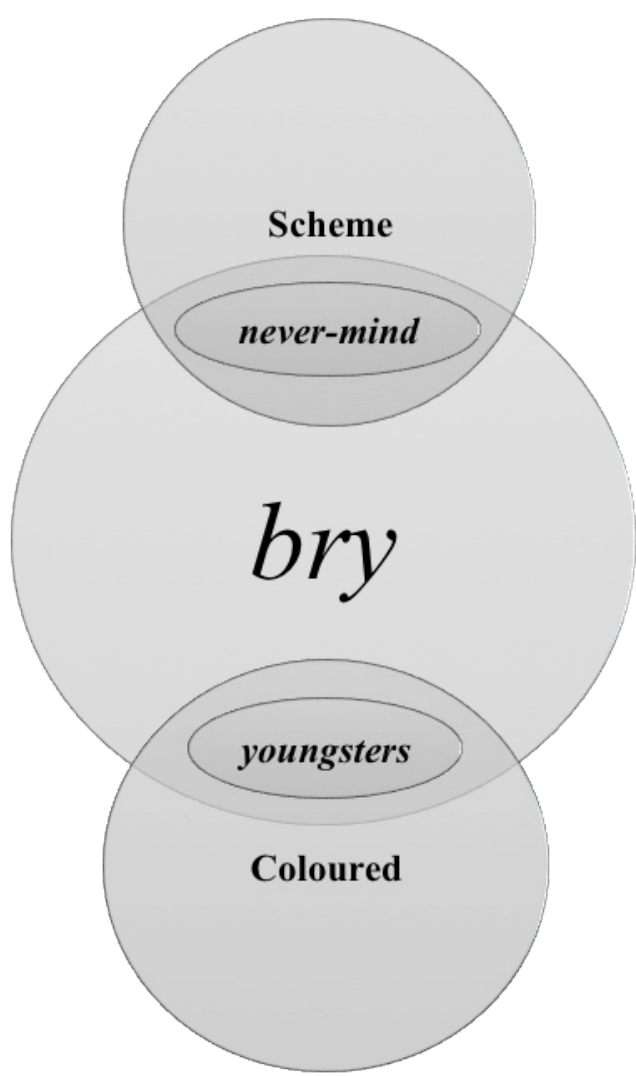

Figure 4. Lionel's discursive formulation of uvular-r indexicality 
brac of events and reference points that they share, and the people they know' (Williams and Stroud, 2010: 40). Lionel described an extremely local version of the people he knew in the Scheme and the styles he associated with them. These kinds of associations a speaker makes between linguistic forms and social styles allow for the development of secondorder indexicalities: uvular-r, used by young people with a never-minded style, indexes specific types of local personae from the Scheme. Furthermore, Lionel also moved to the supra-regional (Wolfram, 2007), where according to him, Coloured speakers in general used the bry. However, a few turns later, he singled out youngsters in the Scheme as the ones socialised into using this variant. I show this schematically in figure 4 .

During our discussion about bry, Lionel made several moves in the 'indexical field' (Eckert, 2008) of uvular-r, never quite settling on one definite meaning. During this interaction, he changed the meaning he associated with bry in response to the type of question I asked. He also made use of both alveolar-r and uvular-r during the interview, indicating that the different $(r)$ variants can have different interactional meanings in the context of the interview. I explore this facet - how (r) variation plays itself out in interaction - below, after I discuss the patterns of frequency of the (r) variants.

\section{Patterns of frequency}

I have followed traditional variationist methods to calculate the patterns of frequency for the $(r)$ variants. Figure 5 shows the sample group of 72 people's use of alveolar-r and uvular-r according to Speech Style (description $\mathrm{n}=3,549$; conversational $\mathrm{n}=3,866 ; \mathrm{N}=7,415){ }^{8}$

Overall, alveolar-r is used more frequently than uvular-r. There is minimal change between the two styles in terms of type of variant used, which indicates that the participants did not necessarily associate either variant with

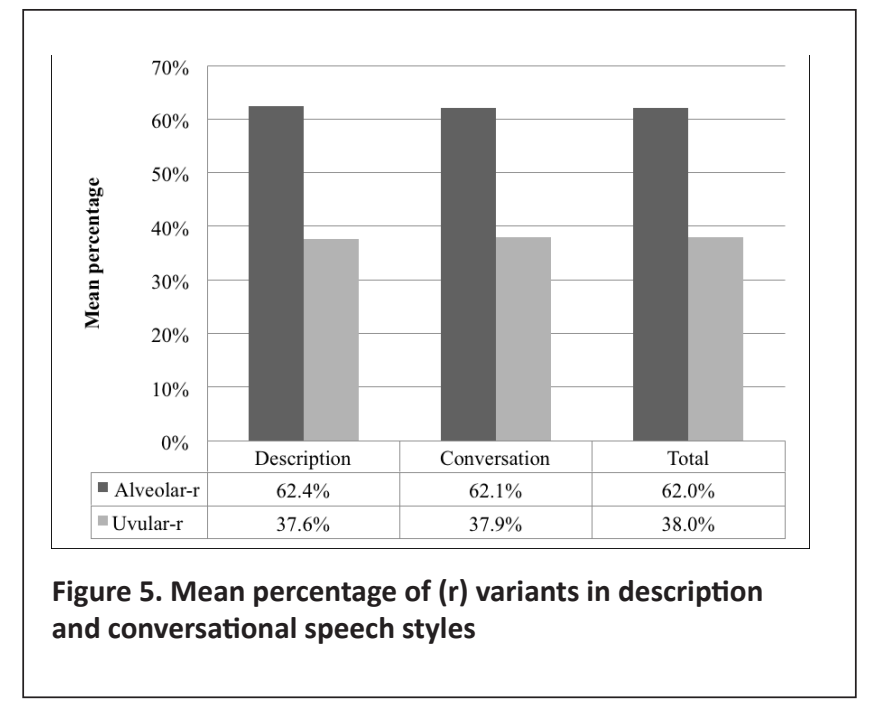

8 Zero-r tokens are excluded. 
a more casual or a more formal style of speech. Based on the statistically significant patterns of (r) use according to the macro-social categories, the occurrence of uvular-r is correlated to the following macro-social types: YOUNG, MEN, OLD DORP, and ESTABLISHED LOCALS. The Venn diagram in figure 6 illustrates this indexical pattern.

Using circles to represent each social category, this diagram shows how they overlap in terms of use of uvular-r. Figure 6 does not explain the social meanings of uvular-r, but indicates what kind of social types it can potentially index through contextual associations. To distinguish between participants who categorically used either variant, and participants who used both, I used a hierarchical and $\mathrm{k}$-means cluster analysis to see whether the 72 participants form clusters according to their (r) use. Thus, only the two $(r)$ variants

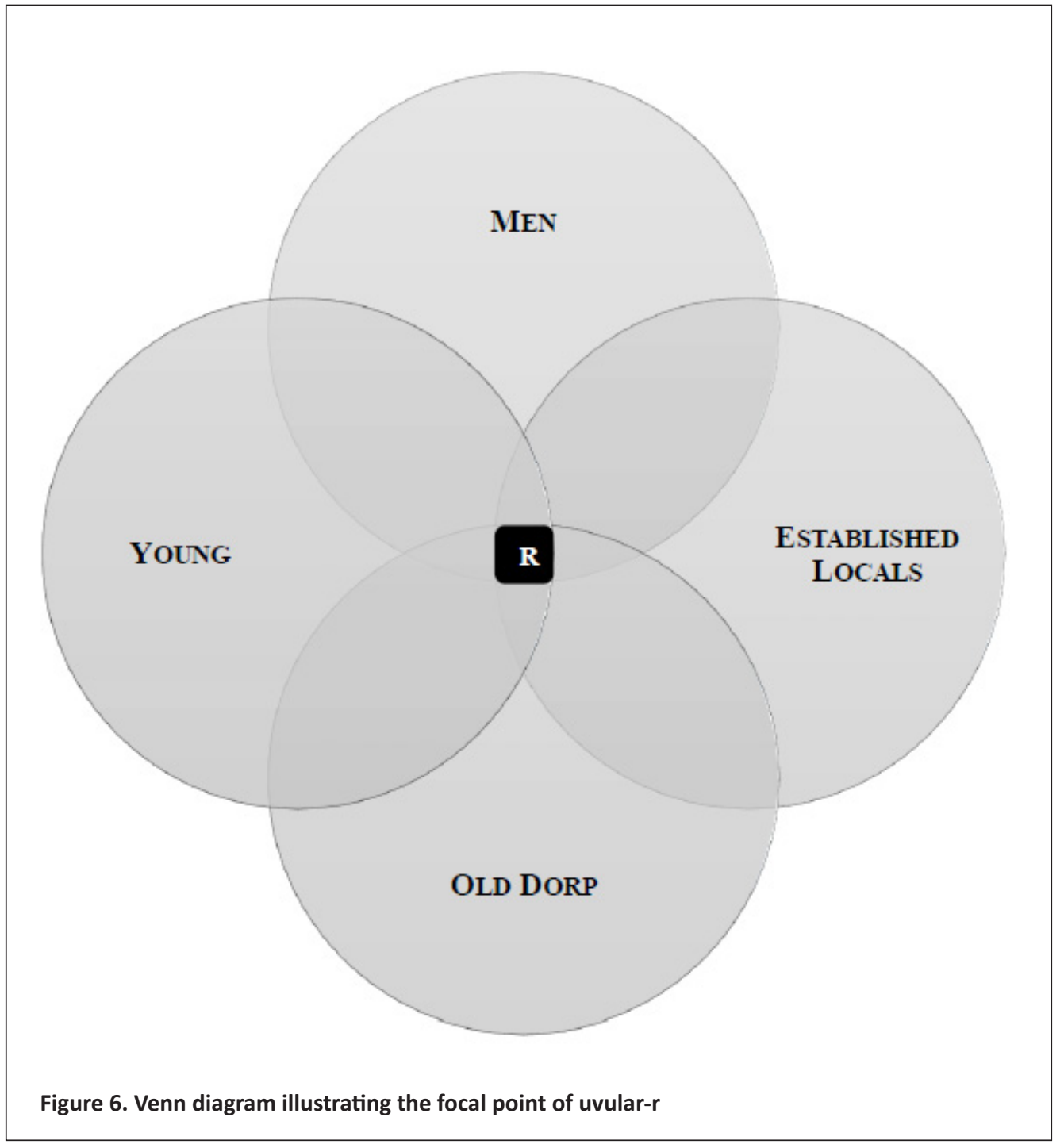


were used to group the participants, not the social variants. The cluster analysis divided the sample group into three groups: near-categorical users of either alveolar-r or uvular-r, and a group with variable use. Figure 7 shows the mean percentage (r) use of the participants in each cluster.

Cluster 1 contains what I refer to as bryers (near-categorical users of uvular-r), Cluster 2 contains near-categorical users of alveolar-r (rollers), and Cluster 3 contains mixers with variable (r) use. The dominance of alveolar-r confirmed above is also reflected in the cluster results; there are more participants in the rollers group $(n=33)$. The cluster results show that the participants had variable (r) use that is not reflected by the statistical averages. Clearly there were participants who used one variant exclusively. Mixed use of both variants applies only to a certain group of participants, and Lionel falls in the group of mixers.

\section{Lionel's patterns of frequency}

Figure 8 shows the mean percentage use of (r) by participants in Lionel's age cohort, which were young women and men younger than 25 .

The figure shows that young men predominantly used uvular-r, while the young women had a more or less equal use of both variants. In the $<25$ age cohort, eleven participants near-categorically used uvular-r (50\%), and four nearcategorically used alveolar-r (18.2\%). Lionel formed part of the group of seven mixers in his age cohort. His average (r) use during the interview was $32 \%$ alveolar-r and $68 \%$ uvular-r.

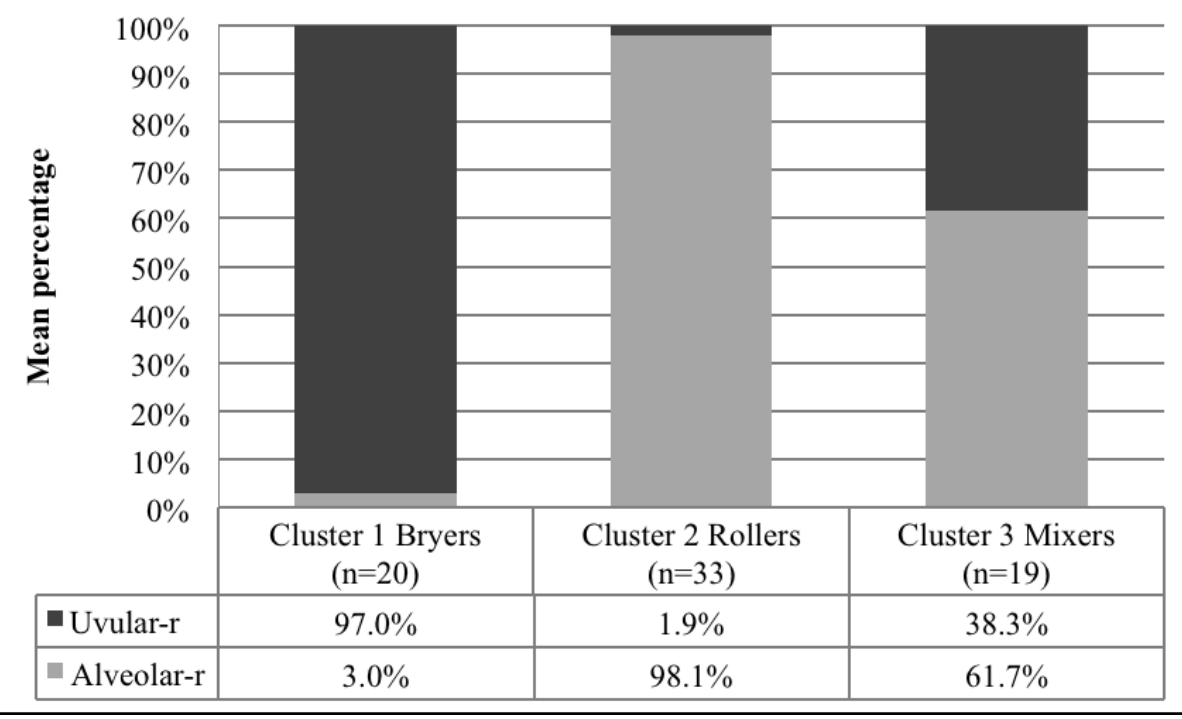

Figure 7. Mean percentage use of $(r)$ for three clusters (group size in brackets) 


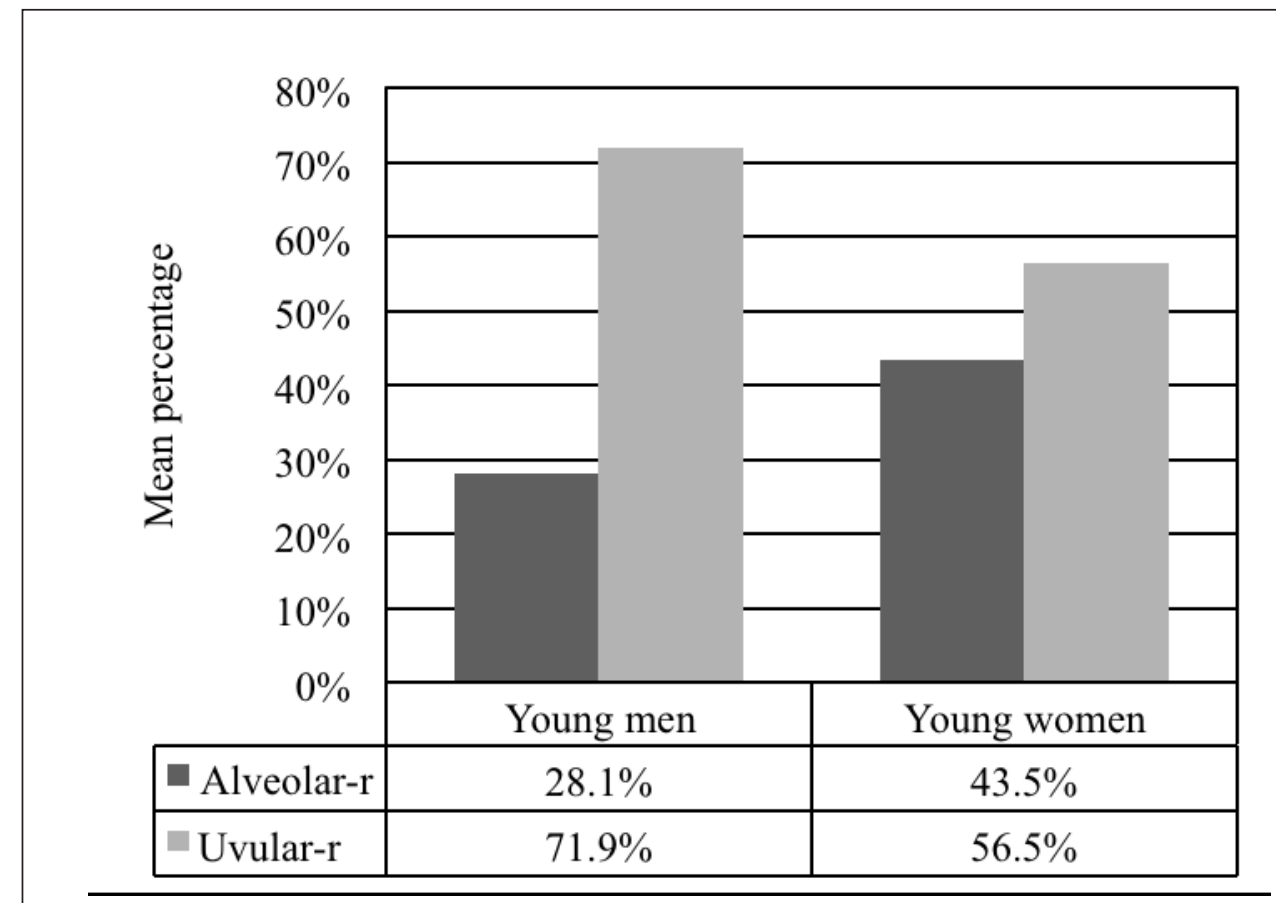

Figure 8. $<25$ cohort's use of $(r)$

\section{'Moments of meaning' in interaction}

Are mixers using uvular-r indiscriminately or does (r) use form interactional clusters during the interview? Where traditional variationist studies prioritise patterns of frequency, Mendoza-Denton (2007) proposes that while the frequency of variants underscores a variant's correlation to social categories, frequency is just one dimension of the social meaning of linguistic forms. The other dimensions are:

A variant's recency (whether it clusters in particular types of discourse and how often it does so), its salience (what it is ideologically associated with), and the agency of the speakers involved (how actively speakers are designing their talk). (Moore and Podesva, 2009: 479)
Indexicality relates to the importance of the frequency with which a linguistic form is used in specific contexts (both physical contexts and in discourse), and by particular types of speakers, which contribute to the indexical associations speakers make between the linguistic form and social meaning. Furthermore, these associations involve ideologies about types of speakers and context, where a variant's recency refers to contextual priming, i.e. previous discursive contexts. Speaker agency is involved when speakers make interactional moves in the indexical field of a variant's multiple and shifting social meanings.

During the interview, I spoke to Lionel about different groups at his high school and he told me about his group of friends. They distinguished themselves from other young men by wearing Grasshopper shoes and playing soccer. 
Shoes and sport seemed important to him and his peers, and he described those who were not part of his group as wearers of other types of shoes, such as Toughies or Bronx. Grasshoppers and Toughies are generic, prescribed South African school shoes. Bronx, a more expensive brand, are formal dress shoes and frequently prohibited by school regulations.
When I asked him whether there was ever any conflict between his group and others, Lionel singled out the young men who played rugby. In excerpt 4 , I shaded the relevant sections in grey (uvular-r sections are in dark-grey and alveolar-r in light-grey; zero-r is indicated with ', e.g. maa'; the original Afrikaans is given).

4) Lionel:

Yolandi

\section{Ja, soos ons die seuns,} onse groupie,

['xRu, pi:]

ons het net Grasshoppers ['gras, Jpərs]

gedra,

[xə'dRa]

die Grassy's.

['gra, si:s]

Lionel:

Yolandi:

Lionel:

Yolandi:

Yes?

Ons almal het dit gedra.

Okay?

Ja [laughs]

En die/

wat het die ander aangehad?

Lionel:

van 'ie,

wie nou?

Yolandi: Wat nie Grasshoppers

aangehad het nie.

Lionel: Nee hulle't ma'die, die,

Toughies,

en daai gehad.

Yolandi: Okay?

Lionel:

$$
\begin{aligned}
& \text { En } \underline{\text { Bronx }} \\
& \text { [bronks] } \\
& \text { en al daai } \\
& \text { [unclear / snaps fingers] }
\end{aligned}
$$

Lionel:

Ons het altyd/
Ons het altyd sokker gespeel,
['so, kəR]
pouses, sokker gespeel.
['so, kəR]

Yes, like we the boys,

our group,

we wore only Grasshoppers,

the Grassy's.

Yes?

All of us wore it.

Okay?

Yes [laughs]

And the/

what did the others wear?

Of the,

who now?

Who didn't wear Grasshoppers.

No they've just had the, the,

Toughies,

and those.

Okay?

and Bronx

and all those

[unclear / snaps fingers]

...

We have always/

We have always played soccer,

break-time, played soccer. 


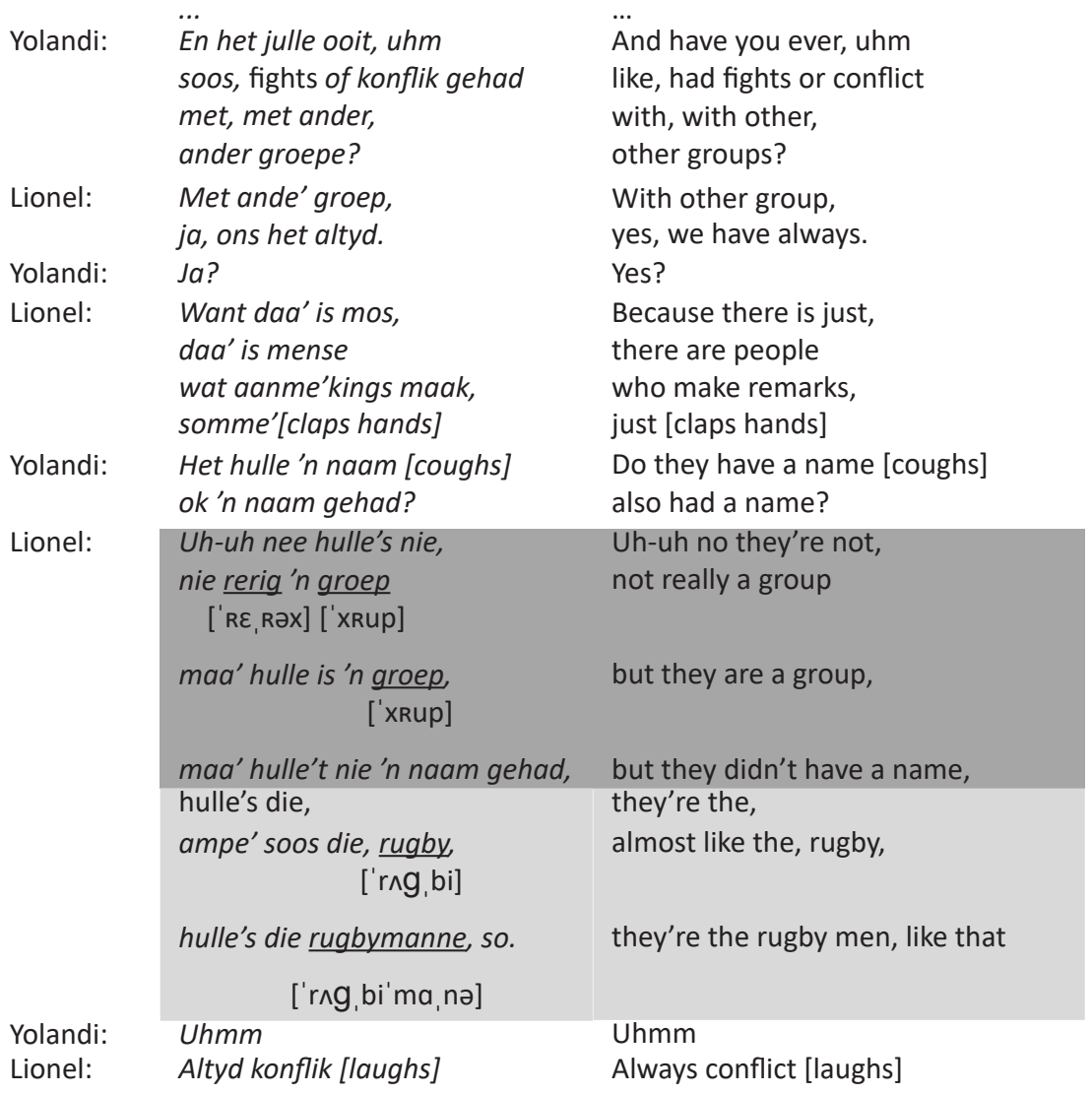

In this short interaction of just over two minutes, Lionel used thirty-nine (r) tokens (including eighteen zero-r); twelve were uvular-r (57.1\%), and nine were alveolar-r (42.9\%). His percentage of uvular-r tokens in this excerpt is in line with his conversational style more generally.

The grey-shaded sections in excerpt 4 show how Lionel moved from talking about his own peer group, to talking about other groups of young men with whom his group experienced conflict. Lionel used uvular-r when discussing the shoes worn by his group, i.e. Grasshoppers, and used alveolar-r when talking about the other group's shoes.
By using uvular-r again in reference to his own group, who are soccer players, he created a semiotic contrast between them and the rugby/Bronx group. He stated that his group was known as die Spa'kies ('the Sparkies'); the other group of students did not have a group name. Instead, they were ones who play rugby, die rugbymanne ('the rugby men'). Lionel uses uvular-r to index his in-group membership of the Spa'kies, whereas alveolar-r indexes 'those from whom he wishes to be distinguished' (Le Page and Tabouret-Keller, 1985: 181).

In South Africa, rugby is a stereotypically hyper-masculine sport, often in contrast to soccer (Anderson 
et al., 2004: 53). In Houtiniquadorp, uvular- $r$ is used more frequently by men. By using alveolar-r when speaking about his group's adversaries, Lionel linguistically diminishes the toughness of the 'rugby men'. At the same time he expresses contrast and indexes belonging by preserving uvular-r for his group of friends. Eckert (2000) shows how the linguistic variation of students in a Detroit high school stylistically corresponds to emic social groups - Jocks and Burnouts - that involved the students' orientation towards the school, suburb, and city, as well as the different clothes and make-up they wear. Similarly, Lionel shows how a combination of uvular-r, Grasshoppers, and soccer can create a particularly local style of Houtiniquadorp's Spa'kies.

Finally, Lionel varies his (r) use within the same topic, which indicates that speakers do not only vary their speech according to broader topics; speakers also vary their speech within one topic. This corresponds to the finding made by the California Style Collective (1993) that the intra-speaker variation of a Californian teenager, nicknamed Trendy, does not only occur with specific topics (e.g. school), but also with subtopics (e.g. descriptions of individual groups within the social milieu of her school). There are what I call key 'moments of meaning' (shaded in grey in excerpt 4) evident in Lionel's interaction, which correspond to his use of either (r) variant. 'Moments of meaning' refer to the ways in which the social meanings of linguistic forms are contextually situated, multiple and emerging in the process of interaction.

\section{CONGLUSION}

This study aimed to explore the processes involved in how linguistic variables attain indexical social meanings by diverging from traditional variationist analyses, which focus on macro-social groups exclusively, to examine how an individual formulates ideologies about linguistic forms and social meaning in concert with his actual language use during interactions. Lionel's metalinguistic comments show that the social meanings of linguistic forms are contextually situated, multiple and emerging in interaction. The fact that he has both (r) variants in his repertoire indicates that he can strategically use linguistic variation to perform different social personae in interaction, exhibiting 'appropriatenessto-context', as well 'effectiveness-incontext' (Silverstein, 2003: 195). The ways that Lionel varied his use of $(r)$ during specific moments in the interview show that the social meanings of a linguistic variant in interaction can move beyond indexing locality and belonging, taking one towards considerations of the variant's use as an index of extremely local in-groups. The idea of 'moments of meaning' foregrounds the fleeting and dynamic aspects of linguistic variation. Rickford and McNair-Knox (1994) and Schilling-Estes (2004) argue that the meaning of intra-speaker variation (i.e. stylistic performances) is related to the interactional moves that speakers make. Looking at "moments of meaning' during interactions allows one to recognise the micro-interactional moves speakers make; speakers can use variants strategically according to topics, etc., which means that variants are not uniformly spread in interactions, but instead correspond to meaningful moments (also see Podesva, 2007). Blommaert (2014: 11-12, 13-14) refers to such moments in interaction as 'a synchronic act of communication' that is 'couched in layers upon layers of relevant contexts.' These 'layers' of contexts are shaped by previous interactions (i.e. recency) and have the potential to shape 
future interactions. Lionel's interaction shows that the manner of a feature's occurrence (its recency) may be just as important as its relative frequency.

\section{REFERENGES}

Adhikari, M. 2006. Hope, fear, shame, frustration: continuity and change in the expression of coloured identity in white supremacist South Africa, 1910-1994. Journal of Southern African Studies 32(3): 467-487.

Anderson, C.M., Bielert, T.A. and Jones, R.P. 2014. One country, one sport, endless knowledge: the anthropological study of sports in South Africa. Anthropologica 46(1): 47-56.

Blommaert, J. 2014. From mobility to complexity in sociolinguistic theory and method. Tilburg Papers in Culture Studies 103:1-24. Available online: < https:// www.tilburguniversity.edu/research/ institutes-and-research-groups/babylon/ tpcs/item-paper-103-tpcs/>

Branford, B. 1996. English in South African society: a preliminary overview. In V. de Klerk Focus on South Africa pp.3551. Amsterdam and New York: John Benjamins.

Bucholtz, M. and Hall, K. 2005. Identity and interaction: a sociocultural linguistic approach. Discourse Studies 7(4-5): 585-614.

California Style Collective. 1993. Personal and Group Style. Paper presented at New Ways of Analyzing Variation. Canada, University of Ottawa.

Christopher, A.J. 2005. The slow pace of desegregation in South Africa's cities, 1996-2001. Urban Studies 42: 2305-2320.

Coupland, N. 2007. Style: Language Variation and Identity. Cambridge: Cambridge University Press.

De Villiers, M. and Ponelis, F.A. 1987. Afrikaanse Klankleer. Cape Town: Tafelberg.

Duranti, A. 2009. Linguistic Anthropology: $A$ Reader $\left(2^{\text {nd }}\right.$ ed.). Malden, MA and Oxford: Wiley-Blackwell.
Eckert, P. 1989. Jocks and Burnouts: Social Categories and Identity in the High School. New York: Teachers College Press.

Eckert, P. 2000. Linguistic Variation as Social Practice: The Linguistic Construction of Identity in Belten High. Oxford: Blackwell.

Eckert, P. 2008. Variation and the indexical field. Journal of Sociolinguistics 12(4): 453-476.

Eckert, P. 2012. Three waves of variation study: the emergence of meaning in the study of sociolinguistic variation. Annual Review of Anthropology 41: 87-100.

Erasmus, Z. 2001. Coloured by History, Shaped by Place: New Perspectives on Coloured Identities in Cape Town. Cape Town: Kwela Books.

Irvine, J.T. and Gal, S. 2000. Language ideology and linguistic differentiation. In P.V. Kroskrity Regimes of Language: Ideologies, Polities, and Identities pp.3584. Santa Fe, NM: School of American Research Press.

Johnson, D.E. 2009. Getting off the GoldVarb standard: Introducing Rbrul for mixed effects variable rule analysis. Language and Linguistics Compass 3(1): 359-383.

Johnstone, B. and Kiesling, S.F. 2008. Indexicality and experience: exploring the meanings of /aw/monophthongization in Pittsburgh. Journal of Sociolinguistics 12(1): 5-33.

Johnstone, B. 2000. The individual voice in language. Annual Review of Anthropology 29: 405-424.

Labov, W. [1966] 2006. The Social Stratification of English in New York City (2 ${ }^{\text {nd }}$ ed.). Cambridge: Cambridge University Press.

Lacoste, V., Leimgruber, J. and Breyer, T. 2014. Authenticity: a view from inside and outside sociolinguistics. In V. Lacoste, J. Leimgruber and T. Breyer (eds.) Indexing Authenticity: Sociolinguistic Perspectives pp.1-13. Berlin: Walter de Gruyter.

Ladefoged, P. and Maddieson, I. 1996. The Sounds of the World's Languages. Malden, MA \& Oxford: Blackwell.

Le Page, R.B. and Tabouret-Keller, A. 1985. Acts of Identity. Creole-based Approaches 
to Language and Ethnicity. Cambridge:

Cambridge University Press.

MAXQDA. VERBI GmbH. 1995-2014.

MAXQDA for Windows, Version 11.

Berlin: VERBI GmbH.

Mendoza-Denton, N. 2007. Sociolinguistic

extensions of exemplar theory:

Comments on Flege, Khattab, and Darcy,

Peperkamp, and Dupoux. In J. Cole and

J.I. Hualde (eds.) Laboratory Phonology 9:

Changes in Phonology. Berlin: Mouton de Gruyter.

Moore, E. and Podesva, R. 2009. 'Style, indexicality, and the social meaning of tag questions'. Language in Society 384: 447-485.

Odendal, F.F. 1989. Afrikaanse fonetiek. In T.J.R. Botha (ed.) Inleiding tot die Afrikaanse Taalkunde pp.155-189. Pretoria: Academica.

Peirce, C.S. 1931-1936. Division of signs. In C. Hartshorne and P. Weiss (eds.) The Collected Papers Volumes 1-6. Cambridge, MA: Harvard University Press.

Peirce, C.S. 1955. Logic as semiotic: the theory of signs. In J. Buchler (ed.) Philosophical Writings of Peirce pp.99-119.

New York: Dover.

Podesva, R.J. 2007. Three Sources of Stylistic Meaning. Texas Linguistic Forum 51. Available online: < http://studentorgs. utexas.edu/salsa/proceedings/2007/ Podesva.pdf $>$

R Core Team. 2014. R: A language and environment for statistical computing. $\mathrm{R}$ Foundation for Statistical Computing, Vienna, Austria. Available online: $<$ http://www.R-project.org/>

Ribbens-Klein, Y. 2016. To bry or not to bry: the social meanings of Afrikaans rhotic variation in the South Cape. $\mathrm{PhD}$ thesis, University of Cape Town.

Ross, R. 2004. Status and Respectability in the Cape Colony, 1750-1870. A Tragedy of Manners. Cambridge: Cambridge University Press.
Schilling-Estes, N. 2002. Investigating stylistic variation. In J.K. Chambers, P. Trudgill and N. Schilling-Estes (eds.) The Handbook of Language Variation and Change pp.375-401. Malden, MA \& Oxford: Wiley-Blackwell.

Scobbie, J.M. 2006. (R) as a variable. In K. Brown (ed.) Encyclopedia of Language $\mathcal{E}^{\circ}$ Linguistics ( $2^{\text {nd }}$ ed.) Volume 10 pp.337344. Oxford: Elsevier.

Silverstein, M. 2003. Indexical order and the dialectics of sociolinguistic life. Language and Communication 23: 193-229.

Silverstein, M. 2006. Reflexivity. In K. Brown (ed.) Encyclopedia of Language $\mathcal{E}^{\circ}$ Linguistics ( $2^{\text {nd }}$ ed.) Volume 10 pp.462463. Oxford: Elsevier.

Statistical Package for the Social Sciences (SPSS). 2012. IBM Corp, IBM SPSS Statistics for Windows, Version 21.0. Armonk, NY: IBM Corp.

StatsSA Statistics South Africa. 2012 Census 2011. Pretoria: Statistics South Africa.

Tops, E. 2009. Variatie en Verandering van de $/ r /$ in Vlaanderen. Brussels: VUBPRESS.

Waldman, L. 2004 Griquatown boorlings and inkommers. In Keywords: Gender pp.1-32. New York: Other.

Waldman, L. 2007 The Griqua Conundrum: Political and Socio-Cultural Identity in the Northern Cape, South Africa. Bern: Peter Lang.

Williams, Q.E. and Stroud, C. 2010. Performing rap ciphas in late-modern Cape Town: extreme locality and multilingual citizenship. Afrika Focus 23(2): 39-59.

Wolfram, W. 2007. Sociolinguistic folklore in the study of African American English. Language and Linguistic Compass 1(4): 1-22.

Woolard, K.A. 2008. Why dat now?: linguistic-anthropological contributions to the explanation of sociolinguistic icons and change. Journal of Sociolinguistics 12(4): 432-452. 